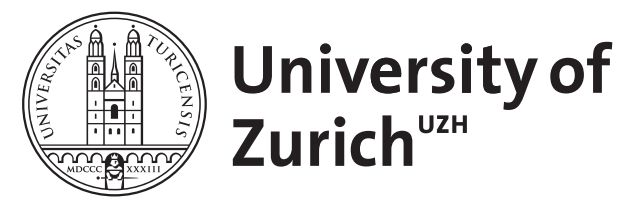

\title{
Immunological memory protective immunity
}

\author{
Zinkernagel, Rolf M
}

\begin{abstract}
So-called 'immunological memory' is, in my view, a typical example where a field of enquiry, i.e. to understand long-term protection to survive reexposure to infection, has been overtaken by 'l'art pour l'art' of 'basic immunology'. The aim of this critical review is to point out some key differences between academic text book-defined immunological memory and protective immunity as viewed from a co-evolutionary point of view, both from the host and the infectious agents. A key conclusion is that 'immunological memory' of course exists, but only in particular experimental laboratory models measuring 'quicker and better' responses after an earlier immunization. These often do correlate with, but are not the key mechanisms of, protection. Protection depends on pre-existing neutralizing antibodies or pre-activated T cells at the time of infection - as documented by the importance of maternal antibodies around birth for survival of the offspring. Importantly, both high levels of antibodies and of activated $\mathrm{T}$ cells are antigen driven. This conclusion has serious implications for our thinking about vaccines and maintaining a level of protection in the population to deal with old and new infectious diseases
\end{abstract}

DOI: https://doi.org/10.1007/s00018-012-0972-y

Posted at the Zurich Open Repository and Archive, University of Zurich ZORA URL: https://doi.org/10.5167/uzh-156214

Journal Article

Published Version

Originally published at:

Zinkernagel, Rolf M (2012). Immunological memory protective immunity. Cellular and Molecular Life Sciences, 69(10):1635-1640.

DOI: https://doi.org/10.1007/s00018-012-0972-y 


\title{
Immunological memory $\neq$ protective immunity
}

\author{
Rolf M. Zinkernagel
}

Received: 10 March 2012/Revised: 13 March 2012 / Accepted: 13 March 2012 / Published online: 6 April 2012

(C) Springer Basel AG 2012

\begin{abstract}
So-called 'immunological memory' is, in my view, a typical example where a field of enquiry, i.e. to understand long-term protection to survive reexposure to infection, has been overtaken by 'l'art pour l'art' of 'basic immunology'. The aim of this critical review is to point out some key differences between academic text book-defined immunological memory and protective immunity as viewed from a co-evolutionary point of view, both from the host and the infectious agents. A key conclusion is that 'immunological memory' of course exists, but only in particular experimental laboratory models measuring 'quicker and better' responses after an earlier immunization. These often do correlate with, but are not the key mechanisms of, protection. Protection depends on preexisting neutralizing antibodies or pre-activated $\mathrm{T}$ cells at the time of infection-as documented by the importance of maternal antibodies around birth for survival of the offspring. Importantly, both high levels of antibodies and of activated $T$ cells are antigen driven. This conclusion has serious implications for our thinking about vaccines and maintaining a level of protection in the population to deal with old and new infectious diseases.
\end{abstract}

Keywords Antibodies - Antigen driven . Maternal antibodies . Acute lethal infection . Non-cytopathic persistent infections

R. M. Zinkernagel ( $\square)$

University of Zurich, 8091 Zurich, Switzerland

e-mail: rolf.zinkernagel@pty.usz.ch

\section{Introduction}

In the beginning was the fact that, once recovered from an infection, the patient was resistant for life to disease by the same infection. This, we call immunity. But since the 1880 s, with the beginning of modern immunology, the term immunological memory was borrowed from 'conventional' (neurological) memory to seemingly explain this fact. We still do not understand whether 'conventional' brain memory is due to once perceived or thought $=$ always remembered, versus repeatedly reencountered, recollected, or dreamed. This controversy is the subject of this review on academic immunological memory versus immunity.

Immunological memory, specificity, and tolerance are three key parameters that immunologists study. Many have reviewed some aspects of this crucial triad of immunity and have voiced serious concerns, not only about the use of these words but also about their implied meaning [1-7]. Immunological memory is defined in text books as follows $[2,3]$ : 'The ability of the immune system to respond more rapidly and effectively to pathogens that have been encountered previously, and that reflects the pre-existence of clonally expanded populations of antigen specific lymphocytes. Memory responses which are called secondary depending on the number of exposures to antigens also differ qualitatively from primary responses. This is particularly clear in the case of the antibody response, where the characteristics of antibodies produced in secondary and subsequent responses are distinct. Specific memory is maintained by distinct populations of long-lived memory cells, that can persist without antigen' [2]. Another definition states [3]: 'Once the immune system has recognized and responded to an antigen, it exhibits immunological memory'. A second encounter with the same antigen 
induces a heightened state of immune reactivity. Because of this attribute, the immune system can confer life-long immunity to many infectious agents after an initial encounter'. The alternative interpretation, that lymphocytes are repeatedly stimulated by antigen re-exposure within the host or from the outside, appears to have been settled in favor of the former type in most immunologists' mind [16]). The key question is, however, whether this 'immunological memory' (i.e. accelerated and heightened response) is good enough to protect the host from either new acutely lethal infections or re-infections for better survival of the species? There is no doubt about experimental documentation of academically defined immunological memory. If a mouse is primed with sheep red blood cells, then a second injection of red cells will reveal an accelerated and heightened response. This also applies to bovine serum albumin, nuclear protein of virus, or classical carrier hapten molecules [1-6]. While accelerated and better responses often correlate with protective immunity, they are alone definitely not sufficient [7-9]. The pre-existing titer of protective antibody or activity of highly activated effector $\mathrm{T}$ cells at the time of infection are generally accepted to determine whether or not a host is protected, or can control, an infection better than a naïve host $[8,10,11]$. In addition, it must be kept in mind that so-called innate or natural immunity is a very important basis for resistance to infection; this includes interferon, Toll-like receptor mediated effects, and so-called natural (non-intentionally) induced antibodies in serum [12]. The latter are highly specific protective antibodies as defined by neutralization assays and by protection. These natural antibodies simply reflect the genetically determined, existing spectrum of the specific B cell repertoire. This includes serotypically defined viral-, bacterial-, or toxin specificities. By definition, such natural antibodies are not cross-reactive but are serotypically specific as formally documented for neutralizing antibodies against viruses [12].

Why should higher vertebrates need 'immunological memory', be it for B cells or T cells? I have been arguing repeatedly [6-9] that if the first infection kills the host, there is no longer any need for immunological memory. Alternatively, if the host can survive the first infection, this indicates that its immune system is capable of dealing with that particular type of infection efficiently, at least during the crucial period necessary for procreation. In evolution, such efficiency is defined by the fact that some percentage of the species survives a primary infection in the absence of a vaccine or any previous exposure. This has been well documented for the middle ages when smallpox first arrived in Europe with mortality rates of up to 80 or $90 \%$ [13], or the more recent myxomatosis exposure of European rabbits in Australia [14].
I summarise as follows: General parameters of immunity

1. Infections by cytopathic/toxic, i.e. acutely lethal agents are controlled by innate plus adaptive resistance mechanisms [1-8]. Non-cytopathic persistent infections are non-pathogenic if an immune response is avoided or reduced $[6,9,15]$; this usually results from $\mathrm{T}$ cell deletion [15] and neutralizing antibody escape by mutation [16]. Remember, however, very low levels of residual infection keeps immunity active by 'infection immunity' [17-20].

2. The immune system only reacts with a timely $\operatorname{IgM}$ or $\mathrm{IgG}$ response if antigen reaches secondary lymphoid organs [21-23].

3. The best correlate of protection against infectious diseases is the pre-existing neutralizing or protective antibody level at the time of exposure to the infection [6-11]. This is best illustrated by the absolute requirement of maternal antibodies in newborns 'and infants' serum and mucosals (from mothers milk) for survival of offspring during the phase of neonatal and early childhood immuno-incompetence $[8,24]$.

4. B cell IgM responses against repetitive multimeric antigens or monomers plus Tlr signals are made in the absence of T help [25-28]. These IgM responses have a short half-life of $\sim 24 \mathrm{~h}$, and of course have a high avidity and superb complement activation capacity. IgA production in the mucosa lamina propria is $\mathrm{T}$ help and secondary lymphoid organ independent [29]. For IgE, these rules are less clear: while specific IgE is strictly $\mathrm{T}$ help dependent, hyper$\operatorname{IgE}$ is not $[30,31]$.

5. ELISA antibody responses usually binding at $10^{5}$ $10^{6} \mathrm{M}^{-1}$ represent highly frequent $\mathrm{B}$ cells $\left(10^{-2}\right.$ $10^{-3}$ ) [32-34], whereas B cells producing neutralizing or protective antibodies with affinities of $>10^{9} \mathrm{M}^{-1}$ in mice or $>10^{10} \mathrm{M}^{-1}$ in humans are rare $<10^{-5}[35,36]$.

6. Affinity maturation, i.e. improvement of binding qualities by somatic mutation is a slow process requiring weeks to months. Obviously, acutely lethal infections that are controlled immunologically must be reflected in the basic antibody (or $\mathrm{T}$ cell) repertoire available at the time of infection [12, 35]. In contrast, non-cytopathic infections that persist may well induce initially low affinity, non-protective antibodies that over time improve by a process of somatic mutation. An example of such a process has been documented for the neutralizing antibody response against LCMV [16, 37-39]. Usually, this process is illustrated with immunological text book 
cases using nitrophenyl- (NP) or oxazolon-specific $\mathrm{IgG}$ responses [40, 41]. However, some of these examples are misleading, because it is usually not an improved original type of anti-NP antibody that binds better to NP. Instead, a newly selected antibody with better binding capacities comes up, and this correlates with a special groove in the binding site of this antibody, into which the small NP fits well. In this context, it is important to remember that relevant biologically active and protective antigenic sites comprise about 7-15 amino acids for contact interactions with a neutralizing antibody [26, 36]. In contrast, academic haptens such as NP are equivalent to only one amino acid. Therefore, it is not surprising that the rules derived from studying hapten-specific antibody responses do not apply to immunity [20, 34]. Also, the concept that highly specific antibodies show broad cross-reactivity is true for small phenylgroup-type haptens or ELISA-measured antibodies to plastic bound proteins, but is not true for complex but well-defined biologically relevant neutralizing antigenic sites [20, 34]. Thus, 'cross reactivity' is seen with antibody binding assays measuring low affinity/ avidity antibodies, but not with serotype-specific protection assays.

7. The classical carrier hapten priming effect is valid for hapten-specific ELISA antibody responses but not for the serotype-specific neutralizing antibody responses against infectious agents. In the first case, where $\mathrm{B}$ cell frequencies are very high $\left(\sim 10^{-2}\right)[32,33,44$, 45], $\mathrm{T}$ help is usually limiting. In the second case of biologically relevant situations, $\mathrm{T}$ helper cells are always in excess and B cell frequency is limiting $\left(\sim 10^{-5}\right)[20,26,34,46]$. I am not contesting the old experimental data of the classical carrier hapten experiments, I simply question their biological relevance. In view of the fact that the only correlate of protection against acute potentially lethal infections is the pre-existing level of neutralizing antibodies (or of already activated T cells) at the time of infection, text book-defined immunological memory-quicker and better $[1-5]$ - is too slow to protect $[6-8,10]$.

8. Protective antibodies against serotypically defined virus or bacteria strains are non-cross-reactive by definition [6, 7, 47], and experimental- or epidemiological evaluation has revealed that cross-reactive antibodies are not protective. Therefore, attempts to raise cross-protective antibodies against Influenza viruses [48-50] or HIV clades [51-53] is useless, has failed so far, and will fail in the future. Rare viruses (or bacteria?) do not comply with this simple rule, e.g., Dengue viruses [54] exhibit defined, but partially overlapping, serotypes correlating with the not yet understood complication of hemorrhagic fever upon certain kinds of cross-reexposure.

9. Spontaneous or not intentionally induced neutralizing antibodies against acute cytopathic agents are specific and not simply a cross-reactive background [12]. They play a major role in reducing early hematogenically spreading antigen. The neutralizing titer of naïve serum against acute cytopathic virus infections is often around 1:30. Note that the difference between spontaneous and protective serum titer (i.e. $>1: 500$ ) is only about 10- to 30-fold. Interestingly, against non-cytopathic viruses, such natural antibody titers usually cannot be measured [12, 16, 38, 39]. In fact, it has been found that protective neutralizing antibody responses against such persistingly noncytopathically infecting viruses (LCMV, HIV, etc.) must undergo slow affinity maturation during which mutational escape is possible (e.g., [16, 38]).

10. Protection requires minimal affinity $10^{-9}$ in mice and $10^{-10}-10^{-11}$ in humans and concentration $>1 \mu \mathrm{g} / \mathrm{ml}$ of protective neutralizing IgG antibody [36].

11. Plasma cells producing protective antibodies are relatively short-lived (1-5 days). Once B cells are fully induced and matured to plasma cells, they get deleted (e.g., [20, 38]). This result of course is in contrast to many studies using ELISA-type antibody responses [5, 55, 56] against haptens [1, 5, 33, 34], but also against viral antigens irrelevant for protection, such as nuclear protein $[20,55]$. However, when the serotype specificity-constraints of the antibody produced by plasma cells are observed, experiments and epidemiology clearly show that only recently activated B cells become neutralizing antibody-producing plasma cells which exhibit a half-life of somewhere between 1 and 5 days [20]. This short half-life is a safe guard against autoantibody-dependent autoimmunity. Therefore, increased $\mathrm{B}$ cell frequencies (or memory B cells) are antigen independent, while maintenance of increased neutralizing antibody levels are antigen dependent [20].

12. Avoidance or delay of a neutralizing antibody response arises from: (1) low precursor B cell frequency [17, 38, 39, 57], (2) requirement of affinity maturation [16, 38, 39, 42], (3) immunopathological destruction of follicle organization in secondary lymphatic tissues [23], (4) variability of the protective antigen [16, 43, 58], and (5) excess $\mathrm{T}$ help causing hyper-IgG responses [59].

13. Sufficient levels of protective antibody must be transferred from mother to offspring via placenta $(\mathrm{IgG})$ and milk (IgA/IgG) to protect the offspring during the 1-2 years after birth against acute cytopathic (childhood) infections. Attenuation of these 
infections by transferred maternal antibody represents the physiological equivalent of vaccination [8, 24].

14. Epidemiologically active conditions are essential to establish active herd immunity against childhood infections [6-8, 11, 24]. It is important that offspring get exposed to epidemiologically active infection during the post-natal period where maternal antibodies are still present to promote enhanced survival and establish acquired immunity [24].

15. Successful vaccines protect humans by neutralizing antibodies via reexposure and immune complexes [6-9, $11,60]$. In contrast, we still lack efficient vaccines that maintain activated $\mathrm{T}$ cell responses (and/or neutralizing antibody responses) against highly variable agents for a long time as is necessary against HIV, HCV, malaria, TB, and many other infections [17, 18, 27, 57, 60].

16. Antigen dependence of protection is often masked by antigen persisting at very low levels in the herd or in the individual, often extralymphatically and sometimes in unconventional forms. This includes persistence of dormant non-replicating infections or crippled virus 'persisting' in the host [6, 7, 11, 60-64] (e.g., Herpes viruses, measles virus) or of DNA forms of conventionally integrated retroviral RNA viruses [53], or through an unconventional DNA form expressed with the help of retroviral elements in the genome of the host $[65,66]$. Reexposure from outside is very commonly unrecognized, particularly for mucosal infections (reviewed in [1-9, 11, 47]).

17. Therefore, immunity represents low level antigendriven immune responses in absence of overt immunopathology in the herd [6-9, 15]. This is best illustrated by antigen derived from reexposure from the outside or the inside of the host by immune complexes [60] (representing antigen depots of several months up to probably years). Low level persistent infections, such as herpes virus infections, TB, leprosy, or HIV constantly reboost immunity. Remember, in the absence of a TB granuloma, protective $\mathrm{T}$ cell immunity fades within 1-2 years, e.g., after BCG immunization, while on the other hand, too many or extensive granulomas eventually cause lethal tuberculosis.

\section{Discussion}

The term immunological memory was originally coined to seemingly understand protective immunity and to explain why and how vaccinations work. Because this definition and the experiments used to support this definition usually had nothing to do with infections (or used infectious disease antigens to study immune memory independent of protection), the apparent correlation was seriously misused, even after improved understanding of both infections and of immune responses became apparent (e.g., [6, 7, 60-64]. The present review is yet another attempt to revise generally held views and to resolve serious discrepancies between the academic ideas on immunological memory and the fact of immunity, i.e. long-term protection against lethal infections. Because words matter and because the immunological community is generally not interested in infectious diseases, the false use of 'memory' to explain protective immunity persists.

The view summarized here, of course, has serious implications not only on the general public's understanding of vaccines and public health but also has a great impact on politics and public support of science. Why do I point this out? Let us assume certain childhood infections against which we have excellent vaccines are now well controlled, but at the 'cost' of reducing epidemiologically circulating wild-type (or live vaccine strain) infections to maintain herd immunity [8, 11, 24, 47]. This is now becoming more obvious as the live-attenuated Sabin vaccine gets phased out (because of the emergence of virulent revertants) [11, 47] and is being replaced by the inactivated Salk vaccine. While until recently the live-attenuated Sabin vaccine repeatedly re-vaccinated the herd, in the future this will not happen. Of course, if there is complete elimination of polio this may not matter. However, unless this has been achieved, any new outbreak of polio would become a great potential disaster, because of exposure of adults and of newborns who possess a level of protection that is insufficient to attenuate initial infections, and therefore cannot allow for disease-free survival of virtually all members of the species. It is now being observed that very early infection with rubella or whooping cough [67, 68] has serious consequences in babies of mothers who had been vaccinated against these agents [with presumably relatively low protective (not necessarily ELISA) antibody titers] in the now altered epidemiological situation-i.e. with nonreplicating vaccine agents and absent or rare re-exposure in the herd in the absence of revaccination. While these are early observations, they at least signal epidemiological conditions where circulating infections and herd immunity may become so low that general maintenance of protection by herd immunity plus vaccinations is not any longer guaranteed [24], unless revaccinations are implemented frequently for perhaps the entire life span.

\section{References}

1. Ahmed R, Gray D (1996) Immunological memory and protective immunity: understanding their relation. Science 272:54-60 
2. Janeway CA, Travers P, Walport M, Shlomchik MJ (2001) Immunobiology: the immune system in health and disease, 5th edn. Garland, New York

3. Goldsby RA, Kindt TJ, Osborne BA (2000) Kuby immunology, 4th edn. Freeman, New York

4. Biron CA (2010) Expansion, maintenance, and memory in NK and $\mathrm{T}$ cells during viral infections: responding to pressures for defense and regulation. PLoS Pathog 6:e1000816

5. Radbruch A, Muehlinghaus G, Luger EO, Inamine A, Smith KG, Dorner T, Hiepe F (2006) Competence and competition: the challenge of becoming a long-lived plasma cell. Nat Rev Immunol 6:741-750

6. Zinkernagel RM (1996) Immunology taught by viruses. Science 271:173-178

7. Zinkernagel RM, Bachmann MF, Kundig TM, Oehen S, Pirchet H, Hengartner H (1996) On immunological memory. Annu Rev Immunol 14:333-367

8. Zinkernagel RM (2001) Maternal antibodies, childhood infections, and autoimmune diseases. N Engl J Med 345:1331-1335

9. Zinkernagel RM, Hengartner H (2004) On immunity against infections and vaccines: credo 2004. Scand J Immunol 60:9-13

10. Steinhoff U, Muller U, Schertler A, Hengartner H, Aguet M, Zinkernagel RM (1995) Antiviral protection by vesicular stomatitis virus-specific antibodies in alpha/beta interferon receptordeficient mice. J Virol 69:2153-2158

11. Hilleman MR (2004) Strategies and mechanisms for host and pathogen survival in acute and persistent viral infections. Proc Natl Acad Sci USA 101(Suppl 2):14560-14566

12. Ochsenbein AF, Fehr T, Lutz C, Suter M, Brombacher F, Hengartner H, Zinkernagel RM (1999) Control of early viral and bacterial distribution and disease by natural antibodies. Science 286:2156-2159

13. Fenner F (1949) Mouse-pox; infectious ectromelia of mice; a review. J Immunol 63:341-373

14. Fenner F (1983) The Florey lecture, 1983. Biological control, as exemplified by smallpox eradication and myxomatosis. Proc $\mathrm{R}$ Soc Lond B 218:259-285

15. Moskophidis D, Lechner F, Pircher H, Zinkernagel RM (1993) Virus persistence in acutely infected immunocompetent mice by exhaustion of antiviral cytotoxic effector $\mathrm{T}$ cells. Nature 362:758-761

16. Ciurea A, Klenerman P, Hunziker L, Horvath E, Senn BM, Ochsenbein AF, Hengartner H, Zinkernagel RM (2000) Viral persistence in vivo through selection of neutralizing antibodyescape variants. Proc Natl Acad Sci USA 97:2749-2754

17. Kundig TM, Bachmann MF, Oehen S, Hoffmann UW, Simard JJ, Kalberer CP, Pircher H, Ohashi PS, Hengartner H, Zinkernagel RM (1996) On the role of antigen in maintaining cytotoxic T-cell memory. Proc Natl Acad Sci USA 93:9716-9723

18. Mackaness GB (1971) Resistance to intracellular infection. J Infect Dis 123:439-445

19. Moll H, Flohe S, Rollinghoff M (1995) Dendritic cells in Leishmania major-immune mice harbor persistent parasites and mediate an antigen-specific $\mathrm{T}$ cell immune response. Eur $\mathrm{J}$ Immunol 25:693-699

20. Ochsenbein AF, Pinschewer DD, Sierro S, Horvath E, Hengartner H, Zinkernagel RM (2000) Protective long-term antibody memory by antigen-driven and $\mathrm{T}$ help-dependent differentiation of long-lived memory B cells to short-lived plasma cells independent of secondary lymphoid organs. Proc Natl Acad Sci USA 97:13263-13268

21. Karrer U, Althage A, Odermatt B, Roberts CW, Korsmeyer SJ, Miyawaki S, Hengartner H, Zinkernagel RM (1997) On the key role of secondary lymphoid organs in antiviral immune responses studied in alymphoplastic (aly/aly) and spleenless (Hox11(-)/-) mutant mice. J Exp Med 185:2157-2170
22. Ochsenbein AF, Pinschewer DD, Odermatt B, Ciurea A, Hengartner H, Zinkernagel RM (2000) Correlation of $\mathrm{T}$ cell independence of antibody responses with antigen dose reaching secondary lymphoid organs: implications for splenectomized patients and vaccine design. J Immunol 164:6296-6302

23. Odermatt B, Eppler M, Leist TP, Hengartner H, Zinkernagel RM (1991) Virus-triggered acquired immunodeficiency by cytotoxic T-cell-dependent destruction of antigen-presenting cells and lymph follicle structure. Proc Natl Acad Sci USA 88:8252-8256

24. Navarini AA, Krzyzowska M, Lang KS, Horvath E, Hengartner H, Niemialtowski MG, Zinkernagel RM (2010) Long-lasting immunity by early infection of maternal-antibody-protected infants. Eur J Immunol 40:113-116

25. Bachmann MF, Hengartner H, Zinkernagel RM (1995) T helper cell-independent neutralizing $\mathrm{B}$ cell response against vesicular stomatitis virus: role of antigen patterns in B cell induction? Eur J Immunol 25:3445-3451

26. Bachmann MF, Rohrer UH, Kundig TM, Burki K, Hengartner H, Zinkernagel RM (1993) The influence of antigen organization on B cell responsiveness. Science 262:1448-1451

27. Roden RB, Greenstone HL, Kirnbauer R, Booy FP, Jessie J, Lowy DR, Schiller JT (1996) In vitro generation and type-specific neutralization of a human papillomavirus type 16 virion pseudotype. J Virol 70:5875-5883

28. Moller G (1975) One non-specific signal triggers B lymphocytes. Transpl Rev 23:126-137

29. Macpherson AJ, Gatto D, Sainsbury E, Harriman GR, Hengartner $\mathrm{H}$, Zinkernagel RM (2000) A primitive $\mathrm{T}$ cell-independent mechanism of intestinal mucosal IgA responses to commensal bacteria. Science 288:2222-2226

30. McCoy KD, Harris NL, Diener P, Hatak S, Odermatt B, Hangartner L, Senn BM, Marsland BJ, Geuking MB, Hengartner H, Macpherson AJ, Zinkernagel RM (2006) Natural IgE production in the absence of MHC Class II cognate help. Immunity 24:329-339

31. Pochanke V, Hatak S, Hengartner H, Zinkernagel RM, McCoy $\mathrm{KD}$ (2006) Induction of IgE and allergic-type responses in fur mite-infested mice. Eur J Immunol 36:2434-2445

32. Bos NA, Meeuwsen CG (1989) B cell repertoire in adult antigenfree and conventional neonatal BALB/c mice. I. Preferential utilization of the CH-proximal VH gene family PC7183. Eur J Immunol 19:1811-1815

33. Eisen HN, Siskind GW (1964) Variations in affinities of antibodies during the immune response. Biochemistry 3:996-1008

34. Gupta SC, Hengartner H, Zinkernagel RM (1986) Primary antibody responses to a well-defined and unique hapten are not enhanced by preimmunization with carrier: analysis in a viral model. Proc Natl Acad Sci USA 83:2604-2608

35. Roost HP, Bachmann MF, Haag A, Kalinke U, Pliska V, Hengartner H, Zinkernagel RM (1995) Early high-affinity neutralizing anti-viral $\operatorname{IgG}$ responses without further overall improvements of affinity. Proc Natl Acad Sci USA 92:1257-1261

36. Bachmann MF, Kalinke U, Althage A, Freer G, Burkhart C, Roost H, Aguet M, Hengartner H, Zinkernagel RM (1997) The role of antibody concentration and avidity in antiviral protection. Science 276:2024-2027

37. Seiler P, Senn BM, Klenerman P, Kalinke U, Hengartner H, Zinkernagel RM (2000) Additive effect of neutralizing antibody and antiviral drug treatment in preventing virus escape and persistence. J Virol 74:5896-5901

38. Hangartner L, Senn BM, Ledermann B, Kalinke U, Seiler P, Bucher E, Zellweger RM, Fink K, Odermatt B, Burki K, Zinkernagel RM, Hengartner H (2003) Antiviral immune responses in gene-targeted mice expressing the immunoglobulin heavy chain of virus-neutralizing antibodies. Proc Natl Acad Sci USA 100:12883-12888 
39. Hangartner L, Zinkernagel RM, Hengartner H (2006) Antiviral antibody responses: the two extremes of a wide spectrum. Nat Rev Immunol 6:231-243

40. Griffiths GM, Berek C, Kaartinen M, Milstein C (1984) Somatic mutation and the maturation of immune response to 2-phenyl oxazolone. Nature 312:271-275

41. Weiss U, Zoebelein R, Rajewsky K (1992) Accumulation of somatic mutants in the B cell compartment after primary immunization with a T cell-dependent antigen. Eur J Immunol 22:511-517

42. Stiegler G, Kunert R, Purtscher M, Wolbank S, Voglauer R, Steindl F, Katinger H (2001) A potent cross-clade neutralizing human monoclonal antibody against a novel epitope on gp41 of human immunodeficiency virus type 1. AIDS Res Hum Retroviruses 17:1757-1765

43. Kimata JT, Kuller L, Anderson DB, Dailey P, Overbaugh J (1999) Emerging cytopathic and antigenic simian immunodeficiency virus variants influence AIDS progression. Nat Med 5:535-541

44. Mitchison NA (1971) The carrier effect in the secondary response to hapten-protein conjugates. V. Use of antilymphocyte serum to deplete animals of helper cells. Eur J Immunol 1:68-75

45. Rajewsky K, Schirrmacher V, Nase S, Jerne NK (1969) The requirement of more than one antigenic determinant for immunogenicity. J Exp Med 129:1131-1143

46. Bachmann MF, Kundig TM, Kalberer CP, Hengartner H, Zinkernagel RM (1994) How many specific B cells are needed to protect against a virus? J Immunol 152:4235-4241

47. Nathanson N, Martin JR (1979) The epidemiology of poliomyelitis: enigmas surrounding its appearance, epidemicity, and disappearance. Am J Epidemiol 110:672-692

48. Doherty PC, Kelso A (2008) Toward a broadly protective influenza vaccine. J Clin Invest 118:3273-3275

49. Song JM, Van Rooijen N, Bozja J, Compans RW, Kang SM (2011) Vaccination inducing broad and improved cross protection against multiple subtypes of influenza A virus. Proc Natl Acad Sci USA 108:757-761

50. Wang TT, Tan GS, Hai R, Pica N, Ngai L, Ekiert DC, Wilson IA, Garcia-Sastre A, Moran TM, Palese P (2010) Vaccination with a synthetic peptide from the influenza virus hemagglutinin provides protection against distinct viral subtypes. Proc Natl Acad Sci USA 107:18979-18984

51. Walker LM, Simek MD, Priddy F, Gach JS, Wagner D, Zwick MB, Phogat SK, Poignard P, Burton DR (2010) A limited number of antibody specificities mediate broad and potent serum neutralization in selected HIV-1 infected individuals. PLoS Pathog 6:e1001028

52. Burton DR (2010) Scaffolding to build a rational vaccine design strategy. Proc Natl Acad Sci USA 107:17859-17860

53. Fauci AS, Johnston MI, Dieffenbach CW, Burton DR, Hammer SM, Hoxie JA, Martin M, Overbaugh J, Watkins DI, Mahmoud
A, Greene WC (2008) HIV vaccine research: the way forward. Science 321:530-532

54. Halstead SB (1989) Antibody, macrophages, dengue virus infection, shock, and hemorrhage: a pathogenetic cascade. Rev Infect Dis 11(Suppl 4):S830-S839

55. Slifka MK, Antia R, Whitmire JK, Ahmed R (1998) Humoral immunity due to long-lived plasma cells. Immunity 8:363-372

56. Manz RA, Thiel A, Radbruch A (1997) Lifetime of plasma cells in the bone marrow. Nature 388:133-134

57. Planz O, Ehl S, Furrer E, Horvath E, Brundler MA, Hengartner H, Zinkernagel RM (1997) A critical role for neutralizing-antibodyproducing B cells, CD4(+) T cells, and interferons in persistent and acute infections of mice with lymphocytic choriomeningitis virus: implications for adoptive immunotherapy of virus carriers. Proc Natl Acad Sci USA 94:6874-6879

58. Borst P, Bitter W, McCulloch R, Van Leeuwen F, Rudenko G (1995) Antigenic variation in malaria. Cell 82:1-4

59. Hunziker L, Recher M, Macpherson AJ, Ciurea A, Freigang S, Hengartner H, Zinkernagel RM (2003) Hypergammaglobulinemia and autoantibody induction mechanisms in viral infections. Nat Immunol 4:343-349

60. Bachmann MF, Kundig TM, Hengartner H, Zinkernagel RM (1994) Regulation of IgG antibody titers by the amount persisting of immune-complexed antigen. Eur J Immunol 24:2567-2570

61. Griffin DE (2010) Measles virus-induced suppression of immune responses. Immunol Rev 236:176-189

62. Riddell MA, Moss WJ, Hauer D, Monze M, Griffin DE (2007) Slow clearance of measles virus RNA after acute infection. J Clin Virol 39:312-317

63. Cattaneo R, Schmid A, Rebmann G, Baczko K, Ter Meulen V, Bellini WJ, Rozenblatt S, Billeter MA (1986) Accumulated measles virus mutations in a case of subacute sclerosing panencephalitis: interrupted matrix protein reading frame and transcription alteration. Virology 154:97-107

64. Katayama Y, Hotta H, Nishimura A, Tatsuno Y, Homma M (1995) Detection of measles virus nucleoprotein mRNA in autopsied brain tissues. J Gen Virol 76(Pt 12):3201-3204

65. Klenerman P, Hengartner H, Zinkernagel RM (1997) A nonretroviral RNA virus persists in DNA form. Nature 390:298-301

66. Geuking MB, Weber J, Dewannieux M, Gorelik E, Heidmann T, Hengartner H, Zinkernagel RM, Hangartner L (2009) Recombination of retrotransposon and exogenous RNA virus results in nonretroviral cDNA integration. Science 323:393-396

67. Rohani P, Zhong X, King AA (2010) Contact network structure explains the changing epidemiology of pertussis. Science 330:982-985

68. Bullens D, Smets K, Vanhaesebrouck P (2000) Congenital rubella syndrome after maternal reinfection. Clin Pediatr (Phila) 39:113-116 